\title{
DEFINING THAT MOMENT
}

The BDJ Upfront section includes editorials letters, news, book reviews and interviews. Please direct your correspondence to the News Editor, Kate Quinlan at the BDJ The Macmillan Building, 4 Crinan Street, London, N1 9XW or by email to k.quinlan@nature.com

Press releases or articles may be edited, and should include a colour photograph if possible.
Stephen Hancocks OBE

Editor-in-Chief
$\mathrm{T}$ he humour of Monty Python's Flying Circus has worked its way into the cultural fabric of our times, as with the question 'what have the Romans ever done for us?' stemming from the film Life of Brian. In this a Roman spokesman answers the question with a stream of positive actions that the Romans have taken to improve the lives of the population and consequently this is often used as shorthand for conveying that a person or organisation under scrutiny has actually done a lot but nobody really comprehends or appreciates it.

Similarly the question is often asked, "what does the BDA do for us?' As above, it is perfectly possible to provide a long and comprehensive list of support, advice, education and many more services which, when presented, elicits the same response, 'yes, but apart from all that what does the BDA do for us?' One element of this list is the annual conference which took place in Manchester earlier this month. As an event it populates many of the items that appear on a list of that which the Association does but in inviting Health Minister Earl Howe to speak it provided a very important centre point to the year's dental agenda.

The main area of interest between the profession and the government is currently the progress towards the terms of the revised NHS dental contact for England. I believe it is fair to say that no one really anticipated that Earl Howe would make any startling new announcements on the subject and as such their expectations were met; there were no new definitive details. However, the Minister did give a very full and honest appraisal of where the reform process resides at present and where

\section{'Yes, but apart from all that what does the BDA do for us?'}

inp
with the existing contract which was
imposed without consultation and
which leaves much to be desired. By consultation and negotiation the $\mathrm{BDA}$ is able to influence the shape and nature of contracts but what it cannot do is make the government, any government, find more money for dentistry. As a profession, irrespective of who represents us, we do not have that level of influence. It might be an unpalatable truth but it is a reality. What is more significant is that none of us has the ability individually or collectively to swim against the tide. Earl Howe made it quite clear that the government fully understands the need to prioritise prevention over treatment; that it comprehends the changing world of oral diseases, notably the

fall in caries and the concomitant shift in dental treatment needs for a population with an overall lower requirement for conventional dentistry; but that it aims to craft the next contract to provide for the flexibility for dentists to exercise their clinical judgment appropriately and organise their practices accordingly. The opportunity to lay out the government's thinking for the benefit of the whole profession may seem merely a polite invitation or a minor nicety but given that not much was expected, what was delivered was highly significant. It signalled that the present administration, arguably better than any of their predecessors, are in the process of facing head-on the nub of the paradox that has overshadowed dentistry from the first moments when we acknowledged the evidence that oral diseases can be prevented. The logical consequence is that the dental profession, if successful in its preventive goals, is in effect working to do itself out of business; to plan its own demise. The next quantum leap in terms of a third-party payer such as the state is to offer a contract that in remuneration terms embodies the transition from 'old' dentistry to 'new' oral care provision and this might be the time which defines that moment.

How many practitioners will wish to accept the terms of the contract no one can guess. Some will undoubtedly not, seeking instead to earn their livelihoods through private practice. Others will complain bitterly that there is not enough money in it, that the government does not understand the dentistry that they were trained to provide and that the BDA has done nothing to help matters; but they will probably sign up anyway. Whether a grudging acceptance of the way the world is travelling will be sufficient to change the nature of dental care within the NHS we will have to wait to see. It will not, however, be a pattern of progress that exists within the NHS alone, private practice will also have to follow a greater and greater preventive emphasis as disease levels fall and the need for conventional intervention falls with them.

The BDA has done and will continue to do very much more but in inviting the Minister to speak, thereby reaching a wide swath of the profession, it has done more than might be immediately imagined in helping to clarify the future.

DOI: 10.1038/sj.bdj.2014.329 